Research, part of a Special Feature on Implementing Participatory Water Management: Recent Advances in Theory, Practice and Evaluation

\title{
Evaluation of Bayesian Networks in Participatory Water Resources Management, Upper Guadiana Basin, Spain
}

\author{
$\underline{\text { Pedro Zorrilla }}^{1}$, Gema Carmona ${ }^{2}$, África De la Hera ${ }^{3}$, Consuelo Varela-Ortega ${ }^{2}$,
} Pedro Martínez-Santos ${ }^{1}$, John Bromley ${ }^{4}$, and Hans Jorgen Henriksen ${ }^{5}$

\begin{abstract}
Stakeholder participation is becoming increasingly important in water resources management. In participatory processes, stakeholders contribute by putting forward their own perspective, and they benefit by enhancing their understanding of the factors involved in decision making. A diversity of modeling tools can be used to facilitate participatory processes. Bayesian networks are well suited to this task for a variety of reasons, including their ability to structure discussions and visual appeal. This research focuses on developing and testing a set of evaluation criteria for public participation. The advantages and limitations of these criteria are discussed in the light of a specific participatory modeling initiative. Modeling work was conducted in the Upper Guadiana Basin in central Spain, where uncontrolled groundwater extraction is responsible for wetland degradation and conflicts between farmers, water authorities, and environmentalists. Finding adequate solutions to the problem is urgent because the implementation of the EU Water Framework Directive requires all aquatic ecosystems to be in a "good ecological state" within a relatively short time frame. Stakeholder evaluation highlights the potential of Bayesian networks to support public participation processes.
\end{abstract}

Key Words: Bayesian networks; decision support system; evaluation; groundwatermanagement; Guadiana Basin; participatory modeling; Spain; water management; water use conflicts

\section{INTRODUCTION}

Stakeholder participation is becoming increasingly important in water resources management (CEC 2000). There are a number of methods to facilitate the involvement of interested parties in decision making, but in many cases it is difficult to evaluate the quality of these methods because of the lack of appropriate benchmarks. This paper describes the development and the evaluation of a participatory decision support system based on Bayesian networks (BNs).

Research was carried out under the NeWater project (New Approaches to Adaptive Water Management under Uncertainty, Mysiak et al. 2010). The project aims to develop tools and strategies to cope with uncertainty, while also promoting the concept of adaptive water management. In this context, BNs were proposed as a suitable approach to underpin water management in the Upper Guadiana Basin in central Spain.

This paper begins with a description of the study area and the research objectives. The focus then shifts to describing and discussing the methodology and the results of the evaluation of the participatory process. The final section is devoted to outlining the main conclusions.

\section{Background}

The Upper Guadiana Basin, in central Spain, presents a set of water-related conflicts. These mostly stem from uncontrolled groundwater extractions, and are rooted in the distant past. Since the 1970s, groundwater abstraction has brought

\footnotetext{
${ }^{1}$ Department of Geodynamics, Faculty of Geological Sciences, Complutense University of Madrid, Spain, ${ }^{2}$ Technical University of Madrid, Department of Agricultural Economics, Spain, ${ }^{3}$ Area of Active Processes and Environmental Quality, Department of Research and Geoscientific Prospective, Geological Survey of Spain (IGME), Spain, ${ }^{4}$ Oxford University School of Geography and the Environment, Centre for Water Research, United Kingdom, ${ }^{5}$ Geological Survey of Denmark and Greenland (GEUS), Copenhagen, Denmark
} 
prosperity to the region by enabling farmers to switch from dryland agriculture to irrigation. However, uncontrolled extractions have considerably depleted the Mancha Occidental aquifer, the area's main water source. This has caused a variety of environmental problems, including the desiccation of Ramsar wetlands (Coleto et al. 2003, Fornés et al. 2005, Llamas 2005), leading to conflicts between stakeholder groups; i.e., environmental conservation groups, farmers' associations, and the Guadiana River Basin Authority. To date, environmental restoration attempts have failed up due to poorly integrated water, environmental, and agricultural policies (Martínez-Santos et al. 2008a,b). One example is the Common Agricultural Policy of the 1980s and 1990s, which favored water-intensive crops by coupling subsidies to production (VarelaOrtega et al. 1998, Varela-Ortega 2007). Besides, control over groundwater extractions is traditionally limited. Only half of the existing wells are registered. For practical purposes, this implies that water authorities are unable to enforce sustainable extraction patterns.

Urgent action is required to comply with European legislation. Indeed, the EU Water Framework Directive (CEC 2000) urges all member states to attain a "good ecological status" of surface and groundwater bodies by 2015 (or at the latest by 2027) (CEC 2000). Thus, the River Basin Authority recently launched the Upper Guadiana Water Plan, a water management initiative which aims at restoring the area's wetlands within the Water Framework Directive deadlines (CHG 2008). The plan is endorsed with $5500 \mathrm{M€}$ over the next 20 years, and incorporates actions such as the purchase of land and water rights from irrigators, or the closure (or legalization) of unlicensed wells. Complementary measures include reforestation and dryland farming. Implementation of the Upper Guadiana Water Plan is, however, subject to uncertainties, which mostly relate to likely budget cuts and to the irrigators' willingness to part with their rights to extract water.

Thus, the main water stakeholders fall into four groups:

- the Guadiana River Basin Authority, which depends on Spain's Ministry for the Environment and is responsible for water policy;
- the Castilla-La Mancha Regional Government, which is responsible for the implementation of agricultural policy;

- farmers, who account for approximately $95 \%$ of the total groundwater withdrawals in the catchment; and

- environmental conservation groups.

There are also other stakeholders, such as urban supply companies and industries, although their role in water conflicts is comparatively minor.

\section{Objectives}

This research addresses a three-fold objective:

1) To develop a decision support system that allows the joint evaluation of different water management options, in regard to both water table levels and the regional economy.

2) To provide a platform for dialogue among key water users, and to improve their knowledge about the water system.

3) To evaluate the ability of BNs to effectively engage stakeholders and to support decision making in complex situations.

\section{Overview of participatory methods}

Several participation techniques have been used to incorporate knowledge, interests, and values into decision making (Rowe and Frewer 2000, Webler and Tuler 2001, CEC 2003, Lynam et al. 2007). Recognizing the strengths and weaknesses of the participatory approach is essential for the correct interpretation of results (Lynam et al. 2007). Moreover, experience shows that the choice of suitable techniques can be a matter of utmost importance (Hare et al. 2003). Group model building, also termed participatory modeling, is a specific subset of public participation methods. Group model building is essentially a method to structure participatory discussions, to try to improve the productivity of group processes (Andersen et al. 2007). This technique has been extensively used in system dynamics, and ultimately aims at obtaining 
a simplified representation of reality through the identification of key variables and their interrelations (Lynam et al. 2007).

Variables in environmental systems are often subject to cause and effect relations. These can be difficult to quantify due to the absence of appropriate data or to poor understanding. In such cases, links are best expressed as probabilities rather than exact values. The chief advantage of this approach is that probabilities convey the uncertainties involved in model inputs and outputs (Charniak 1991). Bayesian networks (BNs) are specifically designed for this purpose. Thus, BNs are best described as directed acyclic graphs which attempt to represent the main variables of a system and their quantified relationships using Bayes' probability theory (Jensen 1996). In other words, BNs provide a probabilistic representation of the relationships between input parameters and their dependent variables.

Like other types of causal diagrams, BNs offer an excellent means to engage stakeholders, elicit knowledge and values, and produce outputs in various formats (Lynam et al. 2007). Furthermore, $\mathrm{BN}$ results can readily summarize information, and BNS can be useful for focusing the dialogue on key issues (Rieman et al. 2001). Another remarkable feature of BNs is that they allow the inclusion of both qualitative and quantitative knowledge. This, combined with the ability to carry out rapid updates and simulations, encourages communication and learning. As a result, some authors conclude that BNs are excellent for strategic considerations (Henriksen et al. 2007). On the other hand, BNs also present some drawbacks. Even if the tool is reasonably straightforward to use, time-intensive training is required to master it. Moreover, BNs are not particularly well suited to dealing with dynamic systems because the computational burden required to solve probabilistic relations increases exponentially with the number of variables (Castelletti and Soncini-Sessa 2007).

BNs have often been used in group model building (Varis 1997, Varis and Kuikka 1997, Cain 2001, Borsuk et al. 2001, Lynam et al. 2002, Cain et al. 2003, Smith and Bosch 2004, Bromley et al. 2005, Martín de Santa Olalla et al. 2005, Baran et al. 2006, Hart et al. 2006, Castelletti and Soncini-Sessa 2007, Croke et al. 2007), but there are relatively few studies that evaluate the potential of BNs as a participatory tool (Rieman et al. 2001, Cain et al.
2003, Henriksen et al. 2007, Henriksen and Barlebo 2008). Within this context, the present paper focuses on the ability of BNs to support stakeholder involvement in water management and decision making, based on subjective stakeholder perceptions of pre-defined criteria under uncertainty.

\section{METHODOLOGY}

The first part of this section focuses on participatory Bayesian netword (BN) development in the Upper Guadiana Basin. A description of the evaluation methods ensues, leading to a discussion as to the potential of BNs to boost public participation.

\section{Participatory process in the Upper Guadiana Basin}

In the Upper Guadiana Basin, a lengthy participatory process took place from 2005 to 2008 in the context of the NeWater project (Mysiak et al. 2010). This participatory process was divided into two parts: in the first two years (2005-2006), five stakeholder meetings were held to discuss water management issues, while meetings in the third and forth years (May 2007-April 2008) were devoted to the construction of BNs. This paper is focused on this second part of the participatory process; however, a brief explanation of previous meetings is also provided (Martínez-Santos et al. 2007).

The need for modeling approaches was established early on, in October 2005, during a meeting between researchers and stakeholders. This meeting followed a thorough stakeholder analysis and engagement process, and served the purpose of establishing the needs for research, tools, and capacity building. The following stakeholder meetings served the purpose of discussing water management issues from a general perspective, allowing stakeholders to discuss agro-economic, institutional, and hydrologic aspects of water management. They were also used to underpin the implementation of hydrological modeling approaches (Martínez-Santos et al. 2008a, 2009). Ensuring confidentiality helped reduce the conflictive atmosphere observed prior to the beginning of the project (Varela-Ortega et al. 2006).

In turn, meetings held over the second half of the project focused on the development of BNs. This process was based on the implementation guidelines 
produced by the MERIT project (Bromley 2005). Due to the existence of a well-established stakeholder core, participants became involved from the very outset, i.e., the problem definition stage. Early stakeholder involvement was important to generate a sense of ownership, as well as to facilitate the acceptance of eventual results (Rowe and Frewer 2000, 2004).

Two BNs were constructed using a specialized software package, HUGIN Researcher 6.9 (Hugin Expert 2008). The first one focused on farm-scale issues, whereas the second dealt with the aquifer scale. Both were built to simulate the outcome of different management actions on two key parameters, namely groundwater levels and the regional and local agrarian economy.

For practical reasons, the number of stakeholders was kept as small as possible, while also ensuring that participants were representative of all existing viewpoints (Rowe and Frewer 2004; Burguess and Chilvers 2006). A list of participants is given in Table 1.

Researchers adopted a variety of roles. These ranged from giving introductory talks to facilitation tasks and feedback collection. The research team attempted to ensure a fair participatory process through a two-way communication procedure (Webler et al 2001, Burgess and Chilvers 2006, Rowe and Frewer 2004). In addition, participants were consulted for their opinion at all stages of the process and were kept informed about each step or of any news concerning the process (Webler et al. 1995, Rowe and Frewer 2000, Von Korff 2006). Furthermore, researchers tried to conduct the process in an unbiased way (Rowe and Frewer 2004, Von Korff 2006).

The BN development process was structured in four steps, starting in May 2007 and finishing in April 2008. Table 2 illustrates the objectives and boundaries of each meeting (Webler et al. 1995, Burgess and Chilvers 2006, Von Korff 2006). For the first meeting, stakeholders were divided in two groups, each of which encompassed stakeholders with relatively similar viewpoints. This was deemed appropriate in order to avoid too much direct confrontation at the beginning (Cain 2001, Bromley 2005, Henriksen et al. 2007). A BN was thus constructed during each session. Researchers then merged both networks and continued filling in the states and the conditional probabilities. Subsequent interviews and meetings served to fine-tune the structure of the networks. Model inputs were also evaluated and updated by the stakeholders. This included several rounds of participation and evaluation activities, which helped to improve results and to incorporate diverse values, interests, and perspectives. These activities also constituted a validation exercise, as stakeholders observed the models to yield realistic results.

\section{Evaluation of the participatory process}

Process evaluation followed the methodology outlined by Abelson et al. (2003), Rowe and Frewer (2004), and Von Korff (2006). These authors emphasize the concept of "what works best when" (Fig. 1); in other words, how the specific results of a study can help evaluate the effectiveness of the participation tool in a way that can be useful in different contexts.

Identifying adequate benchmark criteria is crucial in evaluating participatory approaches. This is because criteria must draw useful insights to help other participatory initiatives. In this case, benchmarks were designed to evaluate the success of the participatory process itself, as well as the quality of the tool (i.e., how well BNs supported participation).

Criteria to evaluate the success of the participatory process

A number of goals for the participatory process were identified (see Objectives). These in turn helped to devise a series of criteria to evaluate the process (Table 3).

Conflict attenuation is also identified as an important criterion by most authors. However, this was not included in the evaluation because it had largely been achieved during the earlier stages of the project (prior to $\mathrm{BN}$ development).

\section{Criteria used to evaluate BNs as a tool in participatory processes}

The criteria used to evaluate the participatory tool belong in three categories (Lynam et al. 2007): capabilities, use, and products. 
Table 1. Participants.

\begin{tabular}{lcl}
\hline \hline Stakeholder group & $\begin{array}{c}\text { Participants } \\
\text { (no.) }\end{array}$ & Role/position within stakeholder organization \\
\hline Guadiana River Basin Authority & 2 & $\begin{array}{l}\text { Head of the River Basin Planning Office. } \\
\text { Technician. }\end{array}$ \\
Regional agricultural authority & 4 & Head and technicians of the Innovation Office. \\
Farmers & 6 & $\begin{array}{l}2 \text { representatives of a farmers' union. } \\
\text { 3 representatives of irrigators' associations. } \\
1 \text { irrigators' lawyer. }\end{array}$ \\
Environmental conservation groups & 4 & $\begin{array}{l}\text { Representatives of the environmental interests in the basin. } \\
\text { Other }\end{array}$ \\
& 4 & $\begin{array}{l}2 \text { water consultants. } \\
\text { 2 external researchers. }\end{array}$
\end{tabular}

The capabilities of the tool refer to its potential to facilitate a successful participatory process. The use of the tool refers to the conditions or context in which the tool is applied, whereas products refer to the results. Table 4 provides more specific definitions.

According to these criteria, the participatory process may be evaluated from different perspectives. An example is the use of existing theory, through summarizing the opinions of researchers and their findings. Other approaches include the use of surveys or interviews, or simply open discussions on key aspects of the process (Rowe and Frewer 2004). In this research, a combination of three methods was used: (1) stakeholder evaluation questionnaires, (2) semi-structured telephone interviews, and (3) the researchers' theoretical assessment (Stewart et al. 1984, Einsidiel et al. 2001, and Henriksen et al. 2007).

Evaluation questionnaires were distributed to stakeholders during a project meeting, straight after the main project results were presented. Fifteen completed questionnaires were returned, representing $75 \%$ of the stakeholders who had participated in the process. This sample was considered sufficiently representative. The questionnaire was kept deliberately simple, with three open questions and ten agree/disagree/don't know questions.

\section{RESULTS}

\section{Bayesian network simulation results}

The effects of two potential actions proposed in the Upper Guadiana Water Plan were simulated with farm and aquifer-scale Bayesian (BNs). These actions include: (1) purchase of irrigation rights by the River Basin Authority, and (2) pumping restrictions to improve farmer compliance (Zorrilla et al. 2007).

The farm-scale BN simulated the combined effects of the price of irrigation rights and the different levels of farmers' compliance with water restrictions (based on percent water volume consumed over the allocated quotas). Outcomes were expressed in terms of water table recovery and farm income. Results show that both measures can make an important contribution to aquifer recovery. However, they also suggest that aquifer recovery needs widespread compliance with water restrictions and a high price for irrigation rights.

The aquifer-scale BN (see Fig. 2 and Appendix 1) reveals that the probability of achieving aquifer recovery by 2027 is relatively low (25-40\%), even with full implementation of the Upper Guadiana Water Plan. Achieving recovery would reduce the current economic production of the agricultural sector by $50 \%$. The number of farmers would decrease by a similar percentage. Aquifer recovery 
Table 2. Description of the participatory process developed using Bayesian networks in the Upper Guadiana Basin (May 2007-April 2008).

\begin{tabular}{lll}
\hline \hline Meeting & Objectives & Tools \\
\hline $\begin{array}{l}\text { 1. Definition } \\
\text { of the system }\end{array}$ & $\begin{array}{l}\text { Identify the most } \\
\text { relevant variables in } \\
\text { the system, including } \\
\text { potential actions and } \\
\text { indicators. }\end{array}$ & $\begin{array}{l}\text { Stakeholders were divided in two } \\
\text { groups, who attended two } \\
\text { different sessions (One } \\
\text { questionnaire for each network): }\end{array}$ \\
& $\bullet \quad \begin{array}{l}\text { representatives of farmers } \\
\text { and the agricultural } \\
\text { administration; and }\end{array}$ \\
& $\bullet \quad \begin{array}{l}\text { representatives of } \\
\text { environmental associations } \\
\text { and the River Basin } \\
\text { Authority. }\end{array}$
\end{tabular}

2. Individual interviews

\section{Plenary meeting}

$\begin{array}{ll}\text { 4. Evaluation } & \text { Check, collect } \\ \text { meeting } & \text { feedback, and } \\ & \text { evaluate the } \\ & \text { preliminary results. }\end{array}$

a) Validate the preliminary network. b) Obtain missing data.

c) Check if the states defined by the data collected were close to reality. changes of the network.

b) Define the probabilities of the states of each variable.
Questionnaire explaining previous Two researches asked work, and asking improvements for:

- $\quad$ structure of the network;

- $\quad$ states of each variable; and

- data collected, with its information source (as a way to improve data transparency).

PowerPoint presentations explaining:

Document and explain the final BNs and their preliminary results. questions from the questionnaire to each stakeholder. were interviewed. Duration: $2 \mathrm{~h}$ per interview. by the slides. Duration: $4 \mathrm{~h}$.

One week before the
Program/Organization Results

Introduction to BNs. Outline of the future steps for $\mathrm{BN}$ construction. BNs were constructed from the beginning during the meeting. Duration: $6 \mathrm{~h}$ per meeting.

Four networks (one by session for each of the two scales).

Answers to the questionnaires.
- $\quad$ structure of the network variable by variable; and
- $\quad$ probabilities that needed to be completed.

Ten representatives of the four stakeholder groups

Open discussions guided Evaluation of the meeting the document was preliminary results. sent to the stakeholders. During the meeting the document guided the discussions

Duration: $2 \mathrm{~h}$.
Validation of the network and the states.

New data and sources of data.

Validated structure of the network. Expert inputs to set probabilities. 
Fig. 1. Method used for the evaluation of the Bayesian networks participatory process and tool, developed in the Upper Guadiana Basin, following the recommendations of Abelson et al. 2003, Rowe and Frewer 2004, and Von Korff 2006.

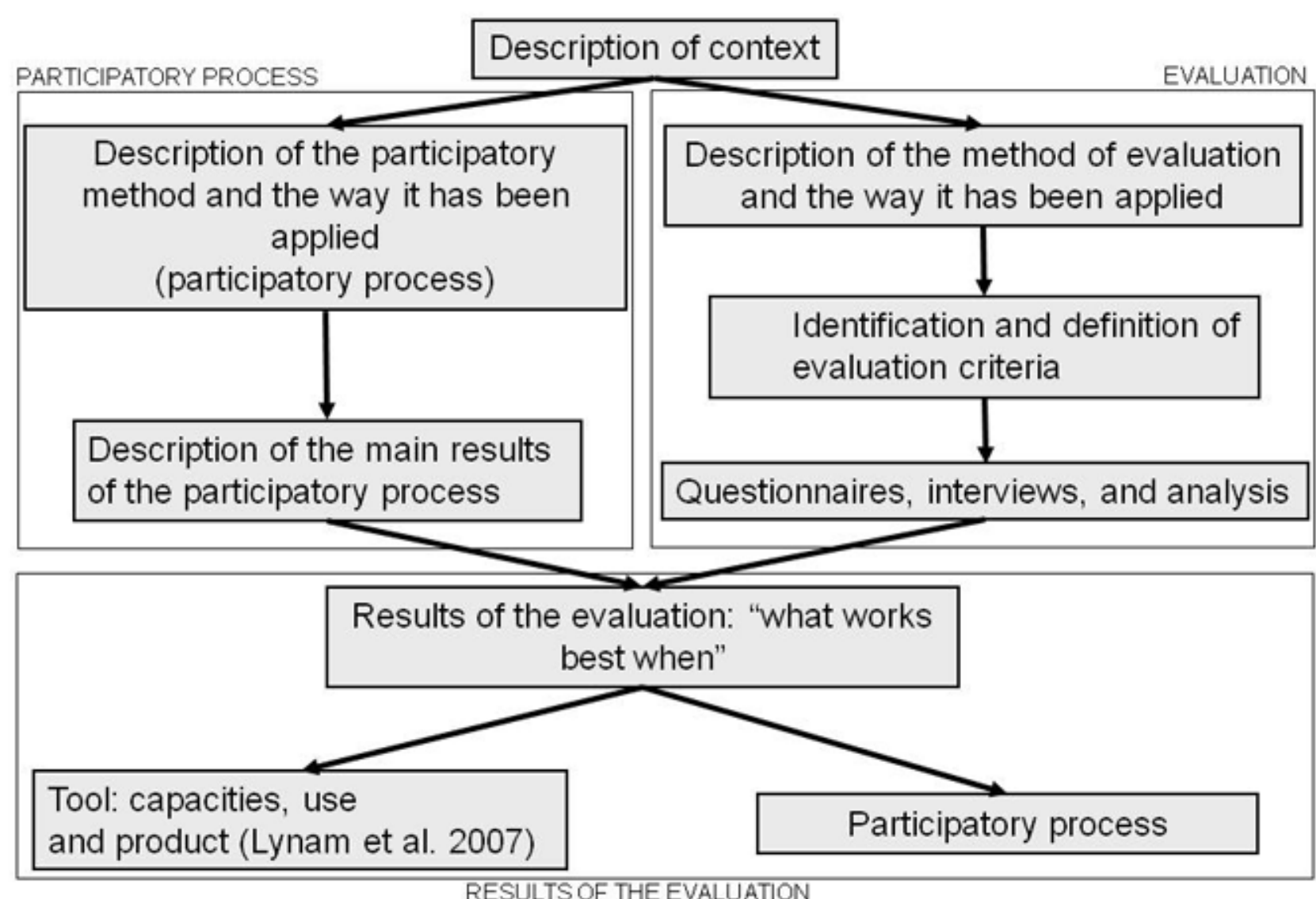

costs can therefore be estimated in economic and social terms and used by decision makers (Zorrilla 2009).

\section{Results of the participatory process evaluation}

Earlier participatory processes held within the NeWater project enabled BNs to focus on technical aspects. The participatory process was evaluated by the stakeholders using the criteria established in the previous section. Table 5 presents an overview of the results. Overall stakeholder response was largely positive, as the majority of participants expressed confidence in the process.
The last objective, foster trust in institutions (criterion 7, Table 3), was not evaluated in the questionnaires. Nevertheless, this is a particularly important issue in the study area, where most stakeholders mistrust each other. It was therefore encouraging to witness the positive attitude of the River Basin Authority throughout the entire process, in which it was among the most active, collaborative, and enthusiastic of participants. This development helped other groups to bolster their confidence in the ability of the River Basin Authority to successfully address water management problems. 
Table 3. Criteria used to evaluate the participatory process, based on the references cited.

\begin{tabular}{lll}
\hline \hline Criteria & Definition of evaluation criteria & Refs. $\dagger$ \\
\hline 1. Useful information & $\begin{array}{l}\text { The process produced data and information that are useful and valid as } \\
\text { a basis for decision making or for further analyses. }\end{array}$ & $4,7,9,10$
\end{tabular}

2. Increase understanding of the concerns of other stakeholder groups

3. Improve system understanding

4. Incorporate stakeholder values, assumptions, and preferences into decision making

5. Assure credibility of the outputs

6. Increase data transparency

7. Foster trust in institutions
The process led to a better understanding among participants (each other's languages, approaches, viewpoints and so forth).

The process enlightened the participants about the most important issues of water management in the area.

The process led participants to discuss values, assumptions and preferences, resulting in their incorporation into analyses and decisions.

The process produced outputs that stakeholders believe to correspond

9 to reality.

The process contributed to solve the problem of data inconsistency due 6,8 to different data sources.

The process increased trust in the University and the River Basin $2,3,6$

$\dagger 1$ - Webler et al. 1995; 2 - Beierle 1998; 3 - Beierle and Konisky 2000; 4 - Rowe and Frewer 2000; 5 - Webler et al. 2001; 6 - Coleto et al. 2003; 7 - Rowe and Frewer 2004; 8 - Llamas 2005;

9 - Burguess and Chilvers 2006; 10 - Lynam et al. 2007.

\section{Evaluation of Bayesian networks as a participatory tool}

Three of the criteria used to evaluate the capability of BNs for participation purposes were included in the questionnaires. Results are shown in Table 6.

Most stakeholders acknowledge that BNs are useful for structuring meetings and encouraging communication and discussions (73\% agree). One of them, however, argued that cultural peculiarities constrained the ability of BNs to drive the process. This is because participants often drifted off to side issues. He also pointed out that stakeholders complained occasionally, usually when they got upset about the debate.
Both the results of telephone interviews and the researchers' judgments suggested that BNs are a useful means to identify the level of knowledge or uncertainty (criterion 9, Table 4). Some specific participant comments support this statement. Take for instance the following: "the process stressed the uncertainties concerning the exact extension of irrigated land, which can be, depending on the source, 130000 ha or 260000 ha", or "BNs are a useful tool for combining data from different sources, and this allowed the integration of those data sources while helping to identify existing gaps in our knowledge".

The present case supports the view that BNs require specific skills from the user (criterion 12, Table 4) 
Table 4. Criteria used to evaluate BNs as a participatory tool, based on the references cited.

\begin{tabular}{lcl}
\hline \hline Criteria & Definition of evaluation criteria & Refs. $\dagger$ \\
\hline
\end{tabular}

\section{Capabilities of BNs}

8. Structure the participatory process

9. Identify the level of knowledge or uncertainty

10.Encourage communication and discussions

11. Graphical interface

Use of BNs

12. Specific skills

13. Resources

\section{Products of BNs}

14. Useful format of the results
Constructing and using BNs structured the process by clarifying policy $1,2,3,4,5$ objectives and system boundaries, and by providing mechanisms for structuring and displaying the decision making procedure

Constructing and using BNs helped to identify the areas where there is a lack or a deficiency in information

Constructing and using BNs encouraged stakeholders to exchange information and views

The graphical visualization of BNs contributed to a better understanding of the system

6

Constructing and using BNs required specific skills from the user

3

Constructing and using BNs required significant time from

3,5 stakeholders

Using BNs produced outputs in a format (probability distributions) that 6 is useful for stakeholders

$\dagger 1$ - Webler et al. 1995; 2 - Rowe and Frewer 2000; 3 - Rowe and Frewer 2004; 4 - Burguess and Chilvers 2006; 5 - Von Korff 2006; 6 - Lynam et al. 2007.

(Lynam et al. 2007). An understanding of probabilistic models is thus necessary to supervise stakeholder inputs. It is also true, however, that a wide range of user-friendly $\mathrm{BN}$ software is available, both commercial and free. Concerning the resources (criterion 13, Table 4), time was a limiting factor. The literature highlights this as a recurring problem (Cain et al. 2003, Henriksen et al. 2007). In the present case, additional time would have allowed the participants to discuss specific issues. In particular, it would have been interesting to discuss what factors would lead farmers to sell water rights to the Guadiana River Basin Authority.
As far as model outputs are concerned, participants noted some advantages and some disadvantages in relation to the format of the results (criterion 14, Table 4). Probability distributions allow the level of uncertainty of any particular result to be specifically represented. They also emphasize that there are significant uncertainties in the predictions, and that these are aggravated by the existence of numerous drivers for change. On the other hand, people are more familiar with absolute numbers than probability distributions, a factor which constrains the effective communication and understanding of the results. 
Fig. 2. Bayesian network of the Upper Guadiana basin at aquifer-scale (Zorrilla 2009). "G and light blue" variables refer to groundwater; "I and blue" represent irrigation variables; "C and light green" variables correspond to climate; "S and brown" variables represent socio-economic scenarios; "L and green" variables relate to irrigated land; and "D and yellow" variables represent rain-fed agriculture. Appendix 1 provides a full representation of the aquifer-scale Bayesian network.

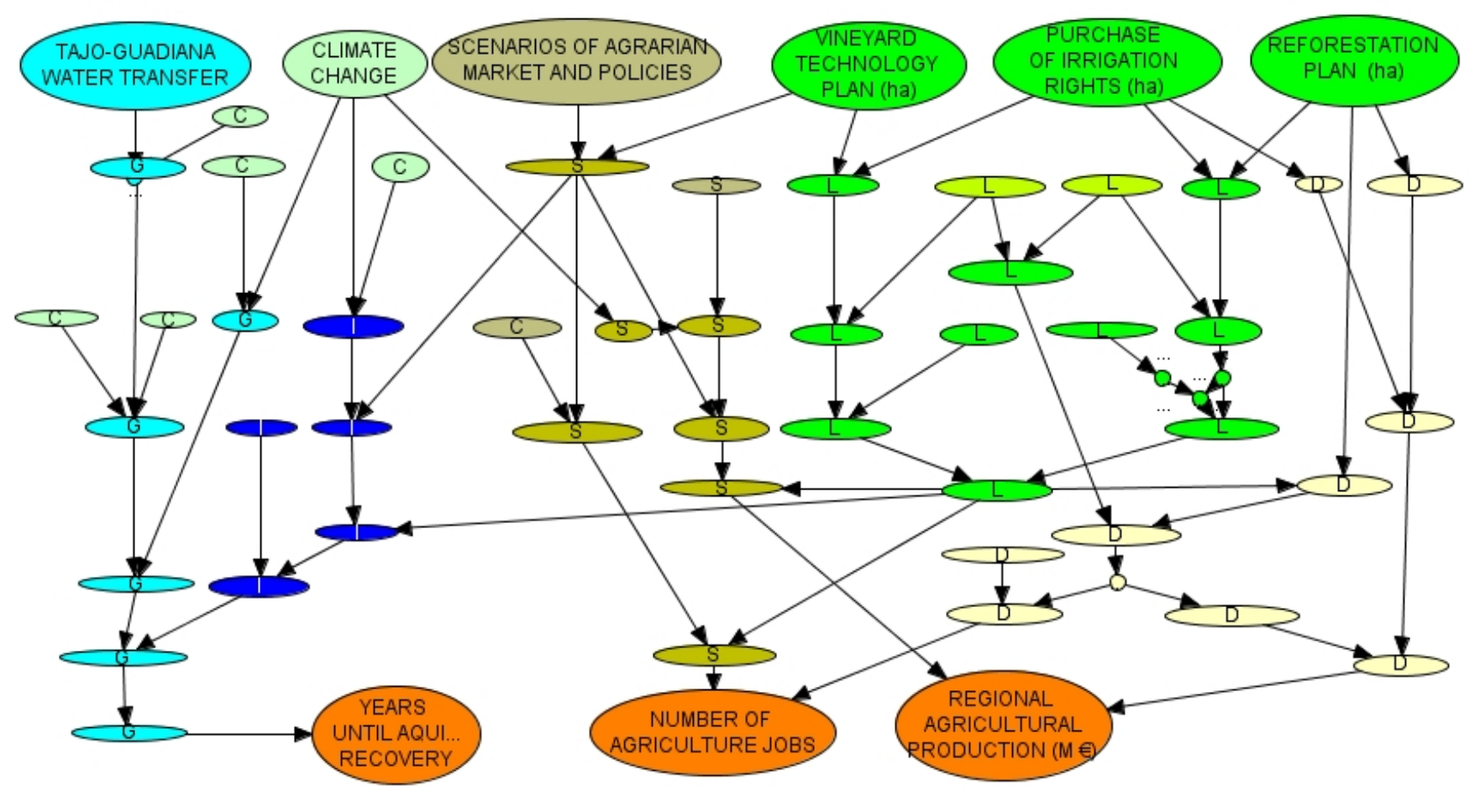

\section{DISCUSSION}

This section begins by comparing the results of this process to the existing literature. The focus then shifts to highlighting some of the strengths and weaknesses of the participatory approach. Finally, the limitations of the evaluation exercise are discussed.

Criterion 4, incorporate stakeholder values into the decision making, received the highest score in the questionnaires (Table 5). This implies that the use of Bayesian networds (BNs) achieved the goal, which is obviously important in any participatory process (Bacon et al. 2002, Lynam et al. 2002). While some authors question the ability of BNs to involve stakeholders other than policy makers (Cain et al. 2003), this case shows that informed stakeholders can effectively contribute to the process. Take for instance the role of farmers and environmentalists, who actively participated in the discussions while also contributing a huge amount of information. Another remarkable outcome from the evaluation questionnaires is that the participatory process increased the understanding of other stakeholder concerns (criterion 2, Table 5) (Henriksen et al. 2007, and Cain et al. 2003).

One of the main advantages of BNs is that they contribute to structuring the participatory process. This is especially useful in contexts such as this, where a public participation tradition is absent (Hernández-Mora 2007, Espluga and Subirats 2008). Stakeholders confirmed that the approach helped give structure and focus to discussions (criterion 8, Table 6), and in this way helped to ease the atmosphere of conflict during the meetings. 
Table 5. Questionnaire-based evaluation.

\begin{tabular}{|c|c|c|c|c|c|c|}
\hline \multirow[b]{3}{*}{ Criteria evaluated } & \multicolumn{6}{|c|}{ Answers } \\
\hline & \multicolumn{2}{|c|}{ Agree } & \multicolumn{2}{|c|}{ Disagree } & \multicolumn{2}{|c|}{ Don't know } \\
\hline & $\mathrm{N}^{\mathrm{o}}$ & $\%$ & $\mathrm{~N}^{\mathrm{o}}$ & $\%$ & $\mathrm{~N}^{\mathrm{o}}$ & $\%$ \\
\hline 1. Useful information & 13 & $87 \%$ & 1 & $7 \%$ & 1 & $7 \%$ \\
\hline $\begin{array}{l}\text { 2. Increase understanding of the concerns of other stakeholder } \\
\text { groups }\end{array}$ & 12 & $80 \%$ & 2 & $13 \%$ & 1 & $7 \%$ \\
\hline 3. Improve system understanding & 13 & $87 \%$ & 2 & $13 \%$ & 0 & $0 \%$ \\
\hline $\begin{array}{l}\text { 4. Incorporate stakeholder values, assumptions and preferences } \\
\text { into decision-making }\end{array}$ & 14 & $93 \%$ & 0 & $0 \%$ & 1 & $7 \%$ \\
\hline 5. Assure credibility of the outputs & 8 & $53 \%$ & 3 & $20 \%$ & 4 & $27 \%$ \\
\hline 6. Increase data transparency & 11 & $73 \%$ & 3 & $20 \%$ & 1 & $7 \%$ \\
\hline
\end{tabular}

The graphical interface of the BNs also proved useful (criterion 11, Table 6). Henriksen and Barlebo (2008) also showed that end-users perceived the graphical model, provided by the $\mathrm{BNs}$, as a strong tool for visualizing complexity. This contributed to the understanding of the relationships between variables, and generated informed discussions at every meeting (criterion 3 , Table 5). This is confirmed by stakeholder perception $(87 \%$ of participants). Similar conclusions were drawn by Lynam et al. (2002), Cain et al. (2003), and Henriksen et al. (2007).

Scores given to criterion 4 confirm the ability of BNs to incorporate values into the decision making process. This is also true of the perceived usefulness of the process $(87 \%$, criterion 1 , Table 5), the increased understanding (criterion 3, Table 5), and the BNs facility to help structure the process (criterion 8, Table 6). Thus, BNs are perceived as an effective means to communicate complex issues and the causes of uncertainty through a graphical interface, as well as to underpin stakeholder dialogue. This in turn implies that BNs can be used to support strategic planning. BNs can also contribute to transparency $(73 \%$, criterion 6 , Table 5) by allowing the stakeholders to have access to background data and knowledge used during the development stage.

Limited confidence in the results $(53 \%$, criterion 5 , Table 5) may be interpreted as an indicator of the situation in the Upper Guadiana Basin, where no win-win solutions appear possible. Broadening the participatory process could thus help identify new strategies. This score also emphasizes that power relations are important when stakeholders are involved, and that BNs never become a shared tool when viewed from the point of view of outcomes. However, a shared process seems to be more important for all parties than a shared outcome (or shared decision support tool). This is because stakeholder interests may lead to different interpretations of the outcomes (Lynam et al. 2002). In other words, the very process of developing the BNs was more important than the final results (Lynam et al. 2002). 
Table 6. Capabilities of BNs as participatory tool.

\begin{tabular}{|c|c|c|c|c|c|c|}
\hline \multirow[b]{3}{*}{ Criteria evaluated } & \multicolumn{6}{|c|}{ Answers } \\
\hline & \multicolumn{2}{|c|}{ Agree } & \multicolumn{2}{|c|}{ Disagree } & \multicolumn{2}{|c|}{ Don't know } \\
\hline & $\mathrm{N}^{\mathrm{o}}$ & $\%$ & $\mathrm{~N}^{\mathrm{o}}$ & $\%$ & $\mathrm{~N}^{\mathrm{o}}$ & $\%$ \\
\hline 8. Structure the participatory process & 11 & $73 \%$ & 2 & $13 \%$ & 2 & $13 \%$ \\
\hline 10. Encourage communication and discussions & 11 & $73 \%$ & 2 & $13 \%$ & 2 & $13 \%$ \\
\hline 11. Graphical interface & 12 & $80 \%$ & 2 & $13 \%$ & 1 & $7 \%$ \\
\hline
\end{tabular}

BNs simplify reality. This is both an advantage and a disadvantage. Conceptualization helps stakeholders to better understand the system. Nevertheless, this can also cause some problems. In the case at hand, some stakeholders wanted the network to cater to complex side issues such as groundwater pollution. While perhaps desirable, this was simply not possible. Thus, the group eventually agreed that the network should only deal with the more pressing concerns.

BNs present a number of advantages over other participatory tools. For one, the graphical interface helps to focus discussions with non-expert stakeholders. BNs trigger multidisciplinary discussions and, due to the use of probability distributions, can explicitly represent uncertainty in the system (criterion 9, Table 4). However, dealing with probabilities presents some inherent disadvantages (criterion 14, Table 4). For instance, Lynam et al. (2007) noted that stakeholders may eventually get bored. In the case at hand, an individual stakeholder put it as follows: "arguing about numbers is tedious". BNs allow this to be bypassed by talking in qualitative terms. These are later translated into numbers by researchers. Translation of single-event probabilities or percentages into frequencies with definitions of reference classes might be one way to help communicate results to the stakeholders, which is something that should be assessed in future studies (Anderson 1998).
Another drawback lies in the construction of conditional probability tables. Stakeholders find it difficult to assign values to some of the variables, particularly to those representing future actions (Cain et al. 2003, Croke et al. 2007). Such reluctance is not surprising. Croke et al. (2007) found that it was difficult to persuade experts to provide probabilities to problems they considered to be extremely complex and impossible to quantify without extensive research. Similarly, Rieman et al. (2001) observed that the use of conditional probabilities explicitly recognizes the limitations in the understanding of the system. Because of the partly subjective origin of some conditional probability tables, results from $\mathrm{BNs}$ can be misinterpreted or misused. This means that outputs should be viewed only as relative trends among alternatives, rather than as absolute numbers.

Considering the evaluation itself, perhaps the main limitation has been the short length of the questionnaire. For future studies, an early evaluation of the BN objectives should be included within the first meetings. Furthermore, an analysis of the efficiency of the tool as perceived from the point of view of different stakeholder positions (policy makers versus technicians, farmers, and environmentalists) should also be introduced. 


\section{CONCLUSIONS}

When reality needs to be modeled, simplification contributes to a better understanding of the different elements within a given system and their interrelations. This is especially important for underpinning social learning in participatory processes, and in helping participants realize the uncertainties involved in the modeling process.

By their very nature, Bayesian networks (BNs) are perceived as effective tools for engaging stakeholders in decision making. BNs enable dialogical learning, while allowing for discussion and negotiation, and this also allows the sources of uncertainty to be explicitly addressed. The steps needed for the construction of a BN help to structure a participatory process. The use of BNs in water planning increases the probability that strategies will be endorsed by stakeholders. In the context of European legislation, BNs may contribute to achieving some of the goals of the EU Water Framework Directive, particularly those related to active involvement of stakeholders in water management.

Responses to this article can be read online at:

http://www.ecologyandsociety.org/vol15/iss3/art12/ responses/

\section{Acknowledgments:}

This research was funded by the EU's NeWater project (Contract number: FP6-2003-GLOBAL-2SUSTDEV-6.3.2-511179-2) (http://www.newater. everyone) and was carried out under the joint collaboration of the Complutense University of Madrid (UCM), the Technical University of Madrid (UPM), the Geological Survey of Spain (IGME), the Geological Survey of Denmark and Greenland (GEUS), and the Centre for Water Research of Oxford University. The authors wish to thank the reviewers for their useful comments, which have greatly improved the manuscript. Professor Ramón Llamas is acknowledged for his steady support and valuable contributions.

\section{LITERATURE CITED}

Abelson, J., P. G. Forest, J. Eyles, P. Smith, E. Martin, and F. P. Gauvin. 2003. Deliberations about deliberative methods: issues in the design and evaluation of public participation processes. Social Science \& Medicine 57(2):239-251.

Andersen, D. F., J. A. M. Vennix, G. P. Richardson, and E. A. J. A. Rouwette. 2007. Group model building: problem structuring, policy simulation and decision support. Journal of the Operational Research Society 58(5):691-694.

Anderson, J. L. 1998. Embracing uncertainty: The interface of Bayesian statistics and cognitive psychology. Conservation Ecology 2(1): 2. [online] URL: http://www.consecol.org/vol2/iss1/art2/

Bacon, P. J., J. D. Cain, M. Kozakiewicz, M. Brzezinski, and A. Liro. 2002. Promoting more sustainable rural land use and development: a casestudy in eastern Europe using Bayesian Network Models. Journal of Environmental Assessment Policy and Management 4(2):199-240.

Baran, E., T. Jantunen, and P. Chheng. 2006. Developing a consultative Bayesian model for integrated management of aquatic resources: an inland coastal zone case study. Pages 206-218 in C. T. Hoanh, T. P. Tuong, J. W. Gowing, and B. Hardy, editors. Environment and livelihoods in tropical coastal zones. CAB International 2006, Wallingford, UK.

Beierle, T. C. 1998. Public participation in environmental decisions: an evaluation framerwork using social goals. Resources for the Future. Discussion paper 99-06. Washington, DC, USA.

Beierle, T. C., and D. M. Konisky. 2000. Values, conflict and trust in participatory environmental planning. Journal of Policy Analysis and Management 19(4):587-602.

Bromley, J. 2005. MERIT Project guidelines: management of the environment and resources using integrated techniques-guidelines for the use of Bayesian networks as a participatory tool for water resource management. Centre for Ecology and Hydrology, Wallingford, UK. 
Bromley, J., N. A. Jackson, O. J. Clymer, A. M. Giacomello, and F. V. Jensen. 2005. The use of Hugin $®$ to develop Bayesian networks as an aid to integrated water resource planning. Environmental Modelling and Software 20(2):231-242.

Borsuk, M. E., Clemen, R. T., Maguire, L.A., and Reckhow, K. H. 2001. Stakeholder values and scientific modeling in the Neuse River Watershed. Group Decision and Negotiation 10:355-373.

Burgess, J., and J. Chilvers. 2006. Upping the ante: a conceptual framework for designing and evaluating participatory technology assessments. Science and Public Policy 33(10):713-728.

Cain, J. 2001. Planning improvements in natural resources management: guidelines for using Bayesian networks to support the planning and management of development programmes in the water sector and beyond. Centre for Ecology and Hydrology. Wallingford, UK.

Cain, J. D., K. Jinapala, I. W. Makin, P. G. Somaratha, B. R. Ariyaratna, and L. R. Perera. 2003. Participatory decision support for agricultural management: a case study from Sri Lanka. Agricultural Systems 76(2):457-482.

Castelletti, A., and R. Soncini-Sessa. 2007. Bayesian Networks and participatory modelling in water resource management. Environmental Modelling \& Software 22:1075-1088.

CEC (Commission of the European Communities). 2000. Directive 2000/60/EC of the European parliament and of the council of 23 October 2000 establishing a framework for community action in the field of water policy. Official Journal of the European Communities L327:1-72.

CEC (Commission of the European Communities). 2003. Common implementation strategy for the water framework directive (2000/60/EC). Guidance Document No 8 Public Participation in Relation to the Water Framework Directive Produced by Working Group 2.9 - Public Participation. Office for Official Publications of the European Communities, Luxembourg.

Charniak, E. 1991. Bayesian networks without tears. AI Magazine 12(4):50-63.

Coleto, C., L. Martínez Cortina, and M. R. Llamas, editors. 2003. Conflictos entre el desarrollo de las aguas subterráneas y la conservación de los humedales: la cuenca alta del Guadiana. Fundación Marcelino Botín, Ediciones Mundi-Prensa, Madrid, Spain.

CHG (Confederación Hidrográfica del Guadiana). 2008. Real Decreto 13/2008, de 11 de enero, por el que se aprueba el Plan Especial del Alto Guadiana. Ministerio de Medio Ambiente. BOE No. 21, 24 January 2008.

Croke, B. F., J. L. Ticehurst, R. A. Letcher, J. P. Norton, L. T. H. Newham, and A. J. Jakeman. 2007. Integrated assessment of water resources: Australian experiences. Water Resource Management 21:351-373.

Einsiedel, E. F., E. Jelsoe, and T. Breck. 2001. Publics at the technology table: The consensus conference in Denmark, Canada, and Australia. Public Understanding of Science 10(1):83-98.

Espluga J., and J. Subirats. 2008. Participación ciudadana en las politicas de agua en España. In Del Moral, L., and Hernández-Mora, N. Panel científico-técnico de seguimiento de la política de aguas. Fundación Nueva Cultura del Agua. (CD Rom) ISBN-13: 978-84-691-0027-1. January 2008, Seville, Spain.

Fornés, J. M., A. de la Hera, and M. R. Llamas. 2005. The silent revolution in groundwater intensive use and its influence in Spain. Water Policy 7:253-268.

Hare, M., R. A. Letcher, and A. J. Jakeman. 2003. Participatory modelling in natural resource management: a comparison of four case studies. Integrated Assessment 4(2):62-72.

Hart B., C. Pollino, T. Chan, M. Grace, N. Mautner, C. Cocklin, T. Walshe, M. Burgman, R. Beilin, D. Fox, A-M. Westbury, D. Tiller, and C. Putt. 2006. Delivering sustainability through risk management, summary. Report to National Program for Sustainable Irrigation (NPSI) by Water Studies Centre, Monash University, Clayton, Victoria, Australia.

Henriksen, H. J., P. Rasmussen, G. Brandt, D. von Bülow, and F. Jensen. 2007. Public participation modelling using Bayesian networks in management of groundwater contamination. Environmental modelling and software 22:1101-1113. 
Henriksen, H. J., and H. C. Barlebo. 2008. Reflection on the use of Bayesian belief networks for adaptive management. Journal of Environmental Management 88:1025-1036.

Hernández-Mora, M. 2007. Participación pública en la gestión de las aguas subterráneas: Visión desde la sociedad civil. Proceeding in Jornadas de la Asociación Internacional de hidrogeólogosGrupo Español "Las aguas subterráneas en España ante las directivas europeas: retos y perspectivas". November 2007, Santiago de Compostela, Spain.

Hugin Expert A/S. 2008. Hugin researcher, version 6.9: user's guide. Aalborg, Denmark. Digital edition.

Jensen, F. V. 1996. An introduction to Bayesian networks. UCL Press, London, UK.

Llamas, M. R. 2005. Lecciones aprendidas en tres décadas de gestión de las aguas subterráneas en España y su relación con los ecosistemas acuáticos. González-Bernáldez Lecture 2005. Universidad Autónoma de Madrid, Madrid, Spain.

Lynam, T., F. Bousquet, C. le Page, P. d'Aquino, O. Barreteau, R. Chinembiri, and B. Mombeshora. 2002. Adapting science to adaptive managers: spidergrams, belief models, and multiagent systems modeling. Conservation Ecology 5 (2):24. [online] URL: http://www.consecol.org/vol5/ iss $2 / \operatorname{art} 24 /$.

Lynam, T., W. de Jong, D. Sheil, T. Kusumanto, and K. Evans. 2007. A review of tools incorportating community knowledge, preferences, and values into decision making in natural resources management. Ecology and Society 12(1):5. [online] URL: http://www.ecologyandsociety.org/voll12/iss1/ art5/.

Martín de Santa Olalla, F. J., A. Domínguez, A. Artigao, C. Fabeiro, and J. F. Ortega. 2005. Integrated water resources management of the Hydrogeological Unit "Eastern Mancha" using Bayesian Belief Networks. Agricultural Water Management 77:21-36.

Martínez-Santos P., L. De Stefano, P. E. Martínez-Alfaro, and M. R. Llamas. $2008 b$. Wetland restoration in the Mancha Occidental aquifer, Spain: a critical perspective on water, agricultural and environmental policies. Restoration Ecology 16(3):511-521.

Martínez-Santos P., H. J. Henriksen, P. Zorrilla, and P.E. Martínez-Alfaro. 2009. Comparative reflections on the use of modelling tools in conflictive water management settings: The Mancha Occidental aquifer, Spain. Environmental Modelling \& Software 25(11):1439-1449. doi:10.1016/ j.envsoft.2008.11.011

Martínez-Santos P., M. R. Llamas, and P. E. Martínez-Alfaro. 2008a. Vulnerability assessment of groundwater resources: a modelling-based approach to the Mancha Occidental aquifer, Spain. Environmental Modelling \& Software 23 (9):1145-1162.

Martínez-Santos P., C. Varela-Ortega, and N. Hernández-Mora. 2007. Making inroads towards adaptive water management through stakeholder involvement, the NeWater experience in the Upper Guadiana Basin, Spain. In Proceedings of the, International Conference on Adaptive and Integrated Water Management (CAIWA), 12-15 November 2007, Basel, Switzerland.

Mysiak, J., H. J. Henrikson, C. Sullivan, J. Bromley, and C. Pahl-Wostl (editors). 2010. The adaptive water resource management handbook. Earthscan, London, U.K.

Rieman, B., J. T. Peterson, J. Clayton, P. Howell, R. Thurow, W. Thompson, and D. Lee. 2001. Evaluation of potential effects of federal land management alternatives on trends of salmonids and their habitats in the interior Columbia River basin. Forest Ecology and Management 153(1-3):43-62.

Rowe, G., and L. J. Frewer. 2000. Public participation methods: a framework for evaluation. Science, Technology \& Human Values 25(19):3-29.

Rowe, G., and L. J. Frewer. 2004. Evaluating public-participation exercises: a research agenda. Science, Technology \& Human Values 29 (4):512-556.

Smith, C. S., and O. J. H. Bosch. 2004. Integrating disparate knowledge to improve natural resource management. In Proceedings of the $13^{\text {th }}$ 
International Soil Conservation Organisation Conference (ISCO 2004), July 2004, Brisbane, Australia. Paper No. 1028.

Stewart, T. R., R. L. Dennis, and D. W. Ely. 1984. Citizen participation and judgment in policy analysis: A case study of urban air quality policy. Policy Sciences 17:67-87.

Varela-Ortega, C. 2007. Policy-driven determinants of irrigation water use and environmental protection: a case study in Spain. Pages 328-346 in F. Molle and J. Berkoff, editors. Irrigation Water Pricing Policy in Context: Exploring The Gap Between Theory and Practice. Comprehensive Assessment of Water Management. CABI Press, Wallingford, UK.

Varela-Ortega, C., I. Blanco, and P. Esteve. 2006. Economic and agronomic aspects of water management in the Upper Guadiana Basin. Stakeholder meeting Report. Newater Project (no 511179) DG Research . EU Commission, Brussels, Belgium.

Varela-Ortega, C., J. M. Sumpsi, A. Garrido, M. Blanco, and E. Iglesias. 1998. Water pricing policies, public decision making and farmers' response: implications for water policy. Agricultural Economics 19(1-2):193-202.

Varis, O. 1997. Bayesian decision analysis for environmental and resource management. Environmental Modelling and Software 12(2-3):177-185.

Varis, O., and S. Kuikka. 1997. BENE-EIA: a Bayesian approach to expert judgement elicitation with case studies on climatic change impacts on surface waters. Climatic Change 37:539-563.

Von Korff, Y. 2006. Towards an evaluation method for public participation processes in AquaStress and NeWater. A proposal for both projects. Unpublished report.

Webler, T., H. Dastenholz, and O. Renn. 1995. Public participation in impact assessment: a social learning perspective. Environmental Impact Assessment Review 15:443-463.

Webler, T., and S. Tuler. 2001. Public participation in watershed management planning: views on process from people to field. Human Ecology Review 8(2):29-39.
Zorrilla, P. (2009). Análisis de la gestión del agua en el acuífero de la Mancha Occidental: construcción de una red bayesiana mediante procesos de participación pública. $\mathrm{PhD}$ Thesis. Faculty of Geological Sciences. Universidad Autónoma de Madrid, Spain.

Zorrilla, P., G. Carmona, A. de la Hera, J. Bromley, H. J. Henriksen, and P. Rasmussen. 2007. Application of Bayesian belief networks to the Upper Guadiana basin. In Proceedings of the, International Conference on Adaptive and Integrated Water Management (CAIWA), 12-15 November 2007, Basel, Switzerland. 
Appendix 1. Bayesian Network of the Upper Guadiana basin at aquifer-scale (Zorrilla 2009). "Light blue" variables refer to groundwater; "Blue" represent Irrigation variables; "Light green" variables relate to non-agriculture water uses and with Climate; "Brown" variables represent Socio-economic Scenarios; "Green" variables refer to Irrigated Land; and "Yellow" variables represent rain fed agriculture.

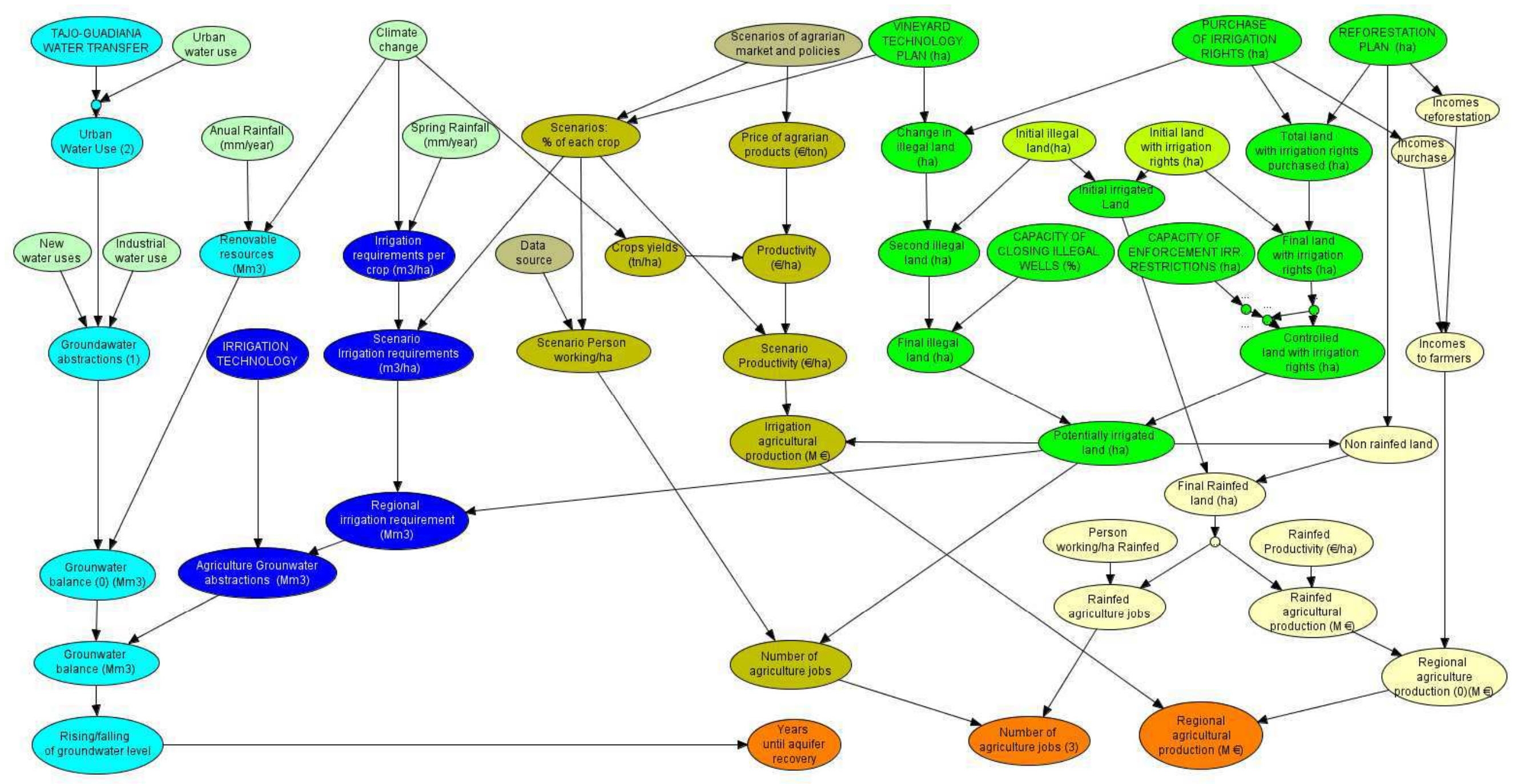

